\title{
The Outcomes of Integrating Concept Mapping in Nursing Education: An Integrative Review
}

\author{
Huthaifah Khrais ${ }^{1}$, Ali Saleh ${ }^{2}$ \\ ${ }^{1}$ School of Nursing, Zarqa University, Zarqa, Jordan \\ ${ }^{2}$ School of Nursing, The University of Jordan, Amman, Jordan \\ Email:h_khrais91@yahoo.com, a_saleh@ju.edu.jo
}

How to cite this paper: Khrais, $\mathrm{H}$. and Saleh, A. (2017) The Outcomes of Integrating Concept Mapping in Nursing Education: An Integrative Review. Open Journal of Nursing, 7, 1335-1347. https://doi.org/10.4236/ojn.2017.711096

Received: October 11, 2017

Accepted: November 27, 2017

Published: November 30, 2017

Copyright ( 92017 by authors and Scientific Research Publishing Inc. This work is licensed under the Creative Commons Attribution International License (CC BY 4.0).

http://creativecommons.org/licenses/by/4.0/

(c) (i) Open Access

\begin{abstract}
Purpose: The purpose of this review was to investigate the current state of knowledge about the effectiveness of concept mapping in nursing education. Methods: An integrative review adapted a systematic approach. Also, after an extensive search from different databases, ten articles were retrieved and fully reviewed. Results: The ten reviewed articles were adopted quantitative, qualitative, and mixed method designs. Four main themes were identified: 1) from passive to active learners, 2) establishing new knowledge, 3) improving cognitive abilities, and 4) self-confidences in clinical work. Conclusion: Nursing literature supports the importance of including concept maps in nursing education. Educators believe that concept mapping is a motivating teaching strategy, hence, it is fostering the long-term and meaningful learning. Also, the findings of this study might encourage nursing educators to evaluate the current teaching strategies, also, this review might initiate future studies with larger sample size.
\end{abstract}

\section{Keywords}

Concept Mapping, Nursing Education, Meaningful Learning, Students

\section{Introduction}

In last two decades, the nursing body of knowledge has increased remarkably, and simultaneously, the current nursing education and health care systems became more complicated. Therefore, nursing educators realize the importance of looking at the nursing education process [1] [2]. It is expected more than ever to prepare graduate nurses who are competent, knowledgeable, and skillful; subsequently safe and quality practice can be achieved [3]. Therefore, undergraduate nursing curricula and their related teaching and learning practices must be 
comprehensively re-evaluated [4].

Issues related to autonomous professional nurses who are able to use reasoned judgment and critical thinking to support clinical decisions are extensively discussed in the literature [5], and hence, these skills are now expected outcomes of nursing undergraduate and graduate programs [6]. However, in order to guide the current nursing education, many educators are striving to explore alternative teaching strategies that promoting an effective meaningful learning rather than sticking with traditional lectures [7] [8].

One of the most effective learning strategies whose effect has frequently been examined and confirmed is the "concept mapping" [9]. Concept mapping was first developed by Joseph D. Novak and Gowin (1984) and their work was grounded based on the theory of meaningful learning [10]. Concept maps provide a graphical arrangement of interrelated concepts and linking lines to clarify the interrelationships of concepts. Novak defines this as "a schematic device for representing a set of concept meanings in a framework of propositions" ([11], p. 18). Hence, students will be directed to link newly-learned concepts with already-learned concepts, which will inevitably help them to change from the traditional way of learning by simply memorizing concepts to integrating concepts meaningfully [12].

Theory of meaningful learning provides a distinctive understanding to construct new knowledge; with an assumption of that the learning is a purposeful process rather than accidental [13]. According to Ausubel, the framework of meaningful learning is about the learner's ability to integrate new knowledge with previously-learned knowledge; that is, meaningful relationships between new and pre-existing concepts are identified. Ausubel refutes "rote memorization" "1 as operating counter to the idea of "meaningful learning" [14]. He also believes that cognitive organization passes through three levels. The first level is "progressive differentiation", in which newly-learned concepts must be organized hierarchically from main concepts to less ordered concepts. Then "subsumption" is needed to link or anchor those new concepts with already-known concepts. Finally, students use "integrative reconciliation" to realize the similarities and differences between new and previously-assimilated knowledge [10]. Through such organized cognitive processing, new concepts can be transferred from short-term memory to long-term memory, which supports the idea of meaningful learning [15].

Concept mapping has the following advantages: it is interactive; it is a valuable visual tool; it is applicable in different educational settings (regular classrooms and clinical areas); it uses many cognitive processes and abilities, and it is very helpful to understand students' learning behaviors [16] [17] [18]. Some studies revealed that concept mapping might positively affect students' critical thinking, emotional intelligence, knowledge acquisition, study engagement, and study achievements [1] [19] [20]. On short term, students who are utilizing concepts

${ }^{1}$ Rote Memorization is learning that only focusing on repetition and memorizing information. 
maps during their study will feel more confident as they can relate and utilize nursing concepts appropriately [21].

Recently, several authors have argued against the effectiveness and usefulness of current passive teaching methods in the nursing context [21]. Indeed, traditional lectures with memorization-centered content do not challenge students, and actually decrease their potential for effective and functional learning [22]. Adding to that, traditional nursing education systems raise many issues about students' genuine absorption of learned information, taking into consideration that faculty members are under continual pressure to deliver large amounts of information within a limited time [23]. Besides, according to Chabeli [13], educators who are content-centered rather than student-centered neglect the importance of linking information meaningfully, and promoting students' memorization, which is expected to be lost over time [24]. Therefore, this paper is aimed to investigate the current state of knowledge about the effectiveness of concept mapping in nursing education.

\section{Materials and Methods}

In this review, the search was performed by different international databases including Google Scholar, Scopus, Web of Science, Science Direct, PubMed, Medline, CINAHL, and EBSCO using the keywords of "concept map", "nurse", "student", "education", and "outcome". These words were searched in combination with each other and in separated form. For example during the initial search, the keyword "concept map" was combined with "nurse". Later, during each new search a new keyword added until including all keywords in the last search.

However, the searching process was limited to following inclusion criteria: 1) Peer-reviewed papers, 2) written in English, 3) published between 2000 and 2017, and 4) specifically related to concept mapping in nursing education. However, review papers and incomplete reports in the form of editorials, opinion pieces, and conference abstracts have been excluded.

Furthermore, a total of 756 articles were retrieved and the initial evaluation for their titles abstracts took place. After evaluating and removing the duplicated articles, only 33 were found to be related to the topic of interest. Then, related articles were printed and read in full, following a secondary evaluation, ten articles were exactly identified to cover the inclusion criteria. As a result, those ten articles were included in this review (see Figure 1).

Also, to extract data from those ten articles, authors were tried to make a data reduction by summarize the main results of each research in a one page. Then to display the data, all summarized pages were collected in a one matrix by using an EXECL sheet. Then, data were compared, coded, and grouped to three themes. However, in order to minimize the expected bias, authors tried to be open minded and report different point views. Also, authors document everything during the process of searching and extracting the data. Then, the work was evaluated by each author independently to ensure objectivity as possible. 


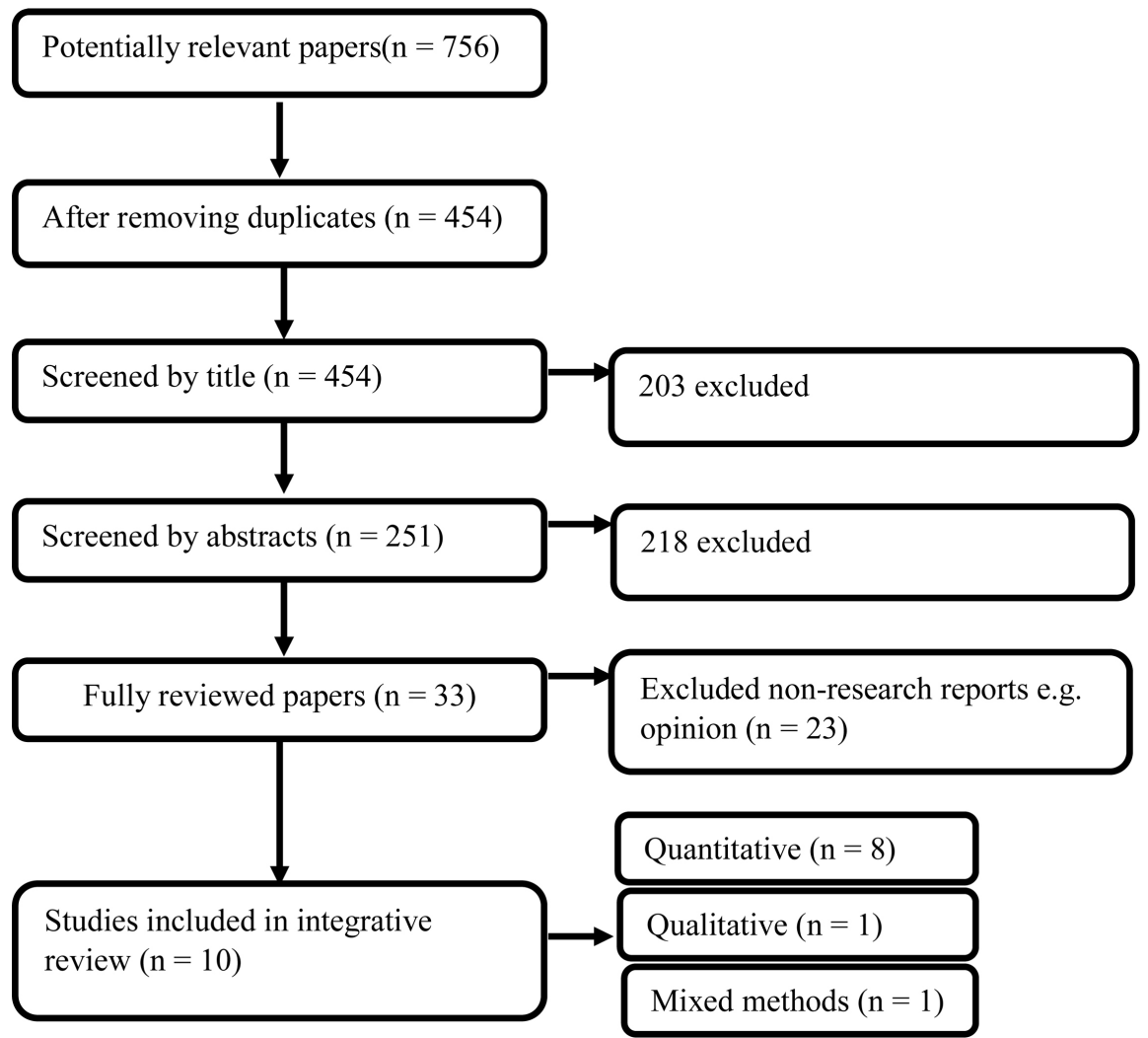

Figure 1. Search strategy and outcomes.

\section{Results}

Ten relevant articles have been reviewed. From each article the following data have been extracted: study purpose, design, sample, and findings (Table 1). Then, authors compared articles, interpreted findings to identify themes, and grouped them based on their similarities.

Overall, the ten reviewed research reports published between 2010 and 2017 (eight quantitative, one qualitative, and one mixed method). Two studies were conducted in USA, two in Taiwan, two in Iran, and one in each of Sweden, Turkey, Egypt, and Brazil. However, to address the purpose of this review, the findings (outcomes of utilizing concept mapping) were categorized into common themes, using a color-coding method to highlight similarities across the literature [24]. The four main themes were the following: 1) transiting students from passive to active learners, 2) establishing new knowledge, 3) improving cognitive abilities, and 4) developing clinically competent nurses.

\subsection{Theme One: Transiting Students from Passive to Active Learners}

As expected, this theme was the most reported in literature. Seven studies stated that concept mapping help students to be more independent learners [25]-[30]. In their qualitative study Trevisani et al. [29] showed how the nursing students experienced a passive behavior to learn with traditional lectures, while they 
Table 1. A summary of the characteristics of the included articles.

\begin{tabular}{|c|c|c|c|c|}
\hline Authors & Purpose & Sample Size & Design & Main Findings \\
\hline $\begin{array}{c}\text { Atay and } \\
\text { Karabacak } \\
\text { (2012), Turkey }\end{array}$ & $\begin{array}{l}\text { To analyze the effects of } \\
\text { care plans prepared using } \\
\text { concept maps on the } \\
\text { critical thinking } \\
\text { dispositions of students. }\end{array}$ & $\begin{array}{l}\quad \mathrm{n}=80 \\
\text { (Females were in } \\
\text { the majority for } \\
\text { both groups) }\end{array}$ & $\begin{array}{l}\text { Experimental } \\
\text { design with } \\
\text { pre-post test. }\end{array}$ & $\begin{array}{l}\text { There were significant differences between } \\
\text { concept map care plan evaluation criteria } \\
\text { mean scores of the experimental students } \\
\qquad(\mathrm{t}=5.37, \mathrm{p}<0.05)\end{array}$ \\
\hline $\begin{array}{l}\text { Chen et al. } \\
\text { (2011), Taiwan }\end{array}$ & $\begin{array}{l}\text { To explore the effects of } \\
\text { concept mapping in } \\
\text { developing critical thinking } \\
\text { ability and approach to } \\
\text { learning and studying. }\end{array}$ & $\begin{array}{l}\quad \mathrm{n}=95 \\
\text { (The mean age } \\
\text { was } 21.98 \text { years) }\end{array}$ & $\begin{array}{l}\text { Quasi-experimental } \\
\text { design }\end{array}$ & $\begin{array}{l}\text { Concept mapping is an effective tool for } \\
\text { improving students' ability to think critically. } \\
\text { (The adjusted means of overall critical } \\
\text { thinking }(\mathrm{F}[1,94]=6.67, \mathrm{p}=0.01) \text { ). }\end{array}$ \\
\hline $\begin{array}{c}\text { Farrag (2017), } \\
\text { Egypt }\end{array}$ & $\begin{array}{l}\text { To evaluate the effect of } \\
\text { concept mapping strategy } \\
\text { for improving maternity } \\
\text { nursing students' } \\
\text { achievement. }\end{array}$ & $\begin{array}{l}\quad \mathrm{n}=125 \\
\text { (The table } \\
\text { indicates that the } \\
\text { mean age of the } \\
\text { study and control } \\
\text { groups was } 19.88 \\
\pm 0.39 \text { and } \\
20.91 \pm 0.50 \\
\text { respectively) }\end{array}$ & $\begin{array}{l}\text { Quasi-experimental } \\
\text { design }\end{array}$ & $\begin{array}{l}\text { Concept mapping significantly enhanced the } \\
\text { students' achievement in the maternity } \\
\text { nursing during the pregnancy course } \\
(\mathrm{t}=-13.1, \mathrm{p}<0.001) \text {. }\end{array}$ \\
\hline $\begin{array}{l}\text { Hagell et al. } \\
\text { (2016), Sweden }\end{array}$ & $\begin{array}{l}\text { To explore group concept } \\
\text { mapping as a tool for } \\
\text { evaluation and } \\
\text { development within } \\
\text { nursing education. }\end{array}$ & $\begin{array}{l}\quad \mathrm{n}=47 \\
\text { (The participants } \\
\text { were } 47(40) \\
\text { females) }\end{array}$ & Mixed method & $\begin{array}{c}\text { Group concept mapping is an interactive } \\
\text { participant centered approach to evaluation, } \\
\text { planning and development in nursing } \\
\text { education. }\end{array}$ \\
\hline $\begin{array}{l}\text { Jaafarpour et al. } \\
\text { (2016), Iran }\end{array}$ & $\begin{array}{l}\text { To assess the concept } \\
\text { mapping as a teaching } \\
\text { method in the academic } \\
\text { achievement of nursing } \\
\text { students. }\end{array}$ & $\begin{array}{c}\mathrm{n}=46 \\
(30(46.87 \%) \\
\text { were males and } \\
34 \text { (53.13\%) were } \\
\text { females) }\end{array}$ & $\begin{array}{l}\text { Quasi-experimental } \\
\text { design }\end{array}$ & $\begin{array}{l}\text { Concept mapping has a positive effect on } \\
\text { students' academic achievement. These } \\
\text { findings could provide valuable evidence for } \\
\text { establishing concept mapping as a continuous } \\
\text { teaching strategy for nursing students (The } \\
\text { results of paired t-test revealed that there was } \\
\text { a significant difference in the mean scores of } \\
\text { CMs }(\mathrm{p}<0.001) \text { ). }\end{array}$ \\
\hline $\begin{array}{l}\text { Kaddoura et al. } \\
\text { (2016), USA }\end{array}$ & $\begin{array}{l}\text { To explore the } \\
\text { development of critical } \\
\text { thinking among nursing } \\
\text { students in a required } \\
\text { pathophysiology and } \\
\text { pharmacology course } \\
\text { during the first year of a } \\
\text { Bachelor of Science in } \\
\text { Nursing in response to } \\
\text { concept mapping as an } \\
\text { interventional strategy, } \\
\text { using the Health Education } \\
\text { Systems, Incorporated } \\
\text { critical thinking test. }\end{array}$ & $\begin{array}{c}\mathrm{n}=42 \\
(8 \text { male and } 33 \\
\text { female) }\end{array}$ & $\begin{array}{c}\text { Two-group } \\
\text { experimental study }\end{array}$ & $\begin{array}{l}\text { Students in the concept mapping group } \\
\text { performed much better on the Health } \\
\text { Education Systems than students in the } \\
\text { control group (students taught with concept } \\
\text { mapping increased their critical thinking } \\
\text { scores by } 84.15 \text { points upon exit from the } \\
\text { course, compared with } 25.24 \text { points among } \\
\text { students not exposed to concept } \\
\text { mapping (p value }<0.0001) \text { ). }\end{array}$ \\
\hline
\end{tabular}


Continued

\begin{tabular}{|c|c|c|c|c|}
\hline $\begin{array}{l}\text { Kaddoura et al. } \\
\text { (2016), USA }\end{array}$ & $\begin{array}{l}\text { To explore how junior } \\
\text { baccalaureate nursing } \\
\text { students perceive the effect } \\
\text { of a concept mapping } \\
\text { educational strategy on the } \\
\text { development of clinical } \\
\text { judgment skills. }\end{array}$ & $\begin{array}{c}\mathrm{n}=106 \\
\quad(89 \% \text { of the } \\
\text { participants were } \\
\text { female, and } 11 \% \\
\text { were male })\end{array}$ & Descriptive study & $\begin{array}{l}\text { The findings revealed that the use of concept } \\
\text { mapping provided an interactive way to } \\
\text { foster the growth of clinical judgment } \\
\text { skills in nursing students. }\end{array}$ \\
\hline $\begin{array}{l}\text { Lee et al. (2013), } \\
\text { Taiwan }\end{array}$ & $\begin{array}{l}\text { To investigate the growth } \\
\text { and the other factors } \\
\text { influencing the } \\
\text { development of critical } \\
\text { thinking in response to } \\
\text { concept map. }\end{array}$ & $\begin{array}{l}\quad \mathrm{n}=95 \\
\text { (All students } \\
\text { were female and } \\
\text { the age ranged } \\
\text { from } 20 \text { to } 26 \\
\text { years with a } \\
\text { mean of } 22.03 \\
\text { years) }\end{array}$ & $\begin{array}{l}\text { Quasi-experimental } \\
\text { and longitudinal } \\
\text { follow-up design }\end{array}$ & $\begin{array}{l}\text { The results of this study showed that } \\
\text { intervention with concept mapping as a } \\
\text { teaching strategy had positive effects on } \\
\text { critical thinking overtime, which implied that } \\
\text { concept map may be useful in helping } \\
\text { students how to think critically } \\
\qquad(\mathrm{t}=-2.55, \mathrm{p}<0.05)\end{array}$ \\
\hline $\begin{array}{l}\text { Sarhangi et al. } \\
\text { (2010), Iran }\end{array}$ & $\begin{array}{l}\text { To compare the effect of } \\
\text { lecture- and concept } \\
\text { mapping based learning } \\
\text { on cognitive learning } \\
\text { levels of nursing } \\
\text { students. }\end{array}$ & $\begin{array}{c}\mathrm{n}=66 \\
(60.6 \% \text { of } \\
\text { students were } \\
\text { female. The } \\
\text { average age of } \\
\text { experimental } \\
\text { group was } 21.23 \\
\text { years and that of } \\
\text { control group } \\
\text { was } \pm 21.21)\end{array}$ & $\begin{array}{l}\text { Quasi-experimental } \\
\text { design }\end{array}$ & $\begin{array}{l}\text { Concept mapping method is more effective in } \\
\text { reaching meaningful learning and high levels } \\
\text { of understanding than traditional lectures } \\
\text { (the meaningful learning mean scores between } \\
\text { groups was statistically significant } \mathrm{p}<0.005 \text { ). }\end{array}$ \\
\hline $\begin{array}{l}\text { Trevisani et al. } \\
\text { (2016), Brazil }\end{array}$ & $\begin{array}{l}\text { To identify whether the use } \\
\text { of concept mapping }(\mathrm{CM}) \\
\text { strategy assists a student to } \\
\text { extend and revise their } \\
\text { expertise in oncology and } \\
\text { analyze the abilities } \\
\text { developed in a student in } \\
\text { order to go through } \\
\text { theoretical to } \\
\text { practical knowledge. }\end{array}$ & $\begin{array}{l}\quad \mathrm{n}=20 \\
(18(90 \%) \text { were } \\
\text { female and } 2 \\
(10 \%) \text { were male. } \\
\text { The age range of } \\
\text { most participants } \\
\text { was } 21-28 \text { years) }\end{array}$ & $\begin{array}{l}\text { Descriptive } \\
\text { qualitative }\end{array}$ & $\begin{array}{l}\text { The results suggested an increase of autonomy } \\
\text { and clinical reasoning in nursing practice. }\end{array}$ \\
\hline
\end{tabular}

showed willingness to think independently with concept mapping. Also, Sarhangi et al. [30] highlighted that concept mapping illustrate students' perceptions about ideas or concepts, which allow them to be aware about their mistakes and motivate students to learn by themselves. These results were supported by Kaddoura, Van-Dyke, and Yang (2016) as they found a positive relation between utilizing concept maps and students potentiality to learn independently. Also, findings from an Egyptian study revealed that learned knowledge from concept mapping is better absorbed and moved to long-term memory, which let students become more eager and keen to learn independently [25].

Further, Hagell and colleagues (2016) stated that the theoretical learned knowledge need to be experienced in an interactive way, as a result, concept mapping provide students with opportunity to test their knowledge actively. 
Kaddoura et al. (2016) and Chen et al. (2011) claim that concept mapping were moved students from rote acquisition of knowledge to deep and meaningful approach to learning, thus, students perceived positive feelings as they actively involved in learning process.

\subsection{Theme Two: Establishing New Knowledge}

Six of the included studies emphasis on the role of concept mapping in constructing new knowledge [16] [25] [29] [30] [31] [32]. Concept mapping, as a teaching method, is flexible enough and allow students to add new concepts and ideas to their cognitive scaffold [31]. Also, Atay and Karabacak [16] and Trevisani et al. [29] found that their students were construct concept maps with new connections and ideas, and they were able to expand their experiences by relating new knowledge with previously learned which is imperative to keep the continuity of nursing education.

From two quasi-experimental studies, students from cardiovascular and maternity courses were notably able to draw creative concept maps that connected with previously learned courses. Accordingly, students abilities to construct knowledge were significantly enhanced their academic achievements by the end of the courses $(\mathrm{p}<0.05)$ [25] [30]. These results were supported by a longitudinal study in Taiwan, in which students show growth in their abilities to link and accumulate knowledge effectively and come up with new ideas [32].

\subsection{Theme Three: Improving Cognitive Abilities}

Organizing students' theoretical material and enabling them to think comprehensively are the goals for any nursing educational program. Many studies in this review stressed the positive effects of concept mapping on cognitive skills (Jaafarpour, Aazami and Mozafari, 2016, Kaddoura, Van-Dyke and Yang, 2016, Lee et al., 2013, Atay and Karabacak, 2012, Chen, et al., 2011). Kaddoura, Van-Dyke, and Yang (2016) found that concept mapping was improving students' critical thinking scores. Further, Atay and Karabacak (2012) and Lee et al. (2013) supported these results as they confirmed a positive relationship between concept mapping and students' critical thinking.

In general, many intellectual abilities such as construction, analysis, inferences as well as meta-cognitive skills might be fostered by concept mapping [16]. Results imply that concept mapping enhanced students' higher ordered cognitive skills, which mean that nursing instructors should not use traditional lectures as the sole method of teaching because as it might hamper students' creativity (Jaafarpour, Aazami and Mozafari, 2016; Chen, et al., 2011).

\subsection{Theme Four: Developing Clinically Competent Nurses}

Within nursing profession students need to integrate theoretical knowledge with clinical practice. Students possess abilities to utilize concept mapping effectively, are more likely to provide holistic nursing care and solve clinical problems 
(Kaddoura, et al. 2016, Trevisani, et al. 2016, Lee, et al. 2013, Chen, et al. 2011). In their studies, Kaddoura et al. (2016) and Lee et al. (2013) found that concept mapping facilitates the transformation of acquired knowledge to clinical practice, decrease students' anxiety, and positively correlated with clinical judgment reasoning. Also, they recommended to integrate concept mapping with clinical scenarios, simulations, and during actual clinical practice. These results were supported by Trevisani et al. (2016) in which concept mapping strategy associated with resolving of clinical situations for patients with oncological diseases. In clinical areas, students can develop a concept map about a given disease, relate patient's data with that concept map, determine the needed clinical skills, make clinical decisions, and develop a multilinear reasoning for the importance of comprehensive care [33].

\section{Discussion}

The current review showed that concept mapping, as a teaching strategy, has worthy outcomes in nursing education. These findings could provide valuable evidences to integrate concept mapping as a continuous teaching strategy in nursing educational programs. The findings were clustered in four themes as following: transiting students from passive to active learners, establishing new knowledge, improving cognitive abilities, and developing clinically competent nurses.

This review revealed that students who participated in concept mapping sessions are likely to be more active and independent learners. Hill (2006) found in here study that concept maps incorporating self-learning techniques and students learned how to acquire knowledge independently and empower themselves to function in the professional setting [34]. Also, by using concept map assessment Rubric, a quasi-experimental study for 102 nursing students revealed that concept mapping is directly correlated with students' abilities to solve problem independently [35]. Beside, concept mapping is able to enhance students' autonomous in completing a relatively unstructured assignment [36].

Another finding from the present review was the importance of concept mapping in constructing new knowledge. This finding is consistent with Hsu et al. [37] study in which concept mapping provides theoretical support for enhancing the construction of neurological care knowledge among nursing students. Basically, through the use of concept maps, educators can potentially assist learners to connect their existing knowledge to new content. This idea is supported clearly when 25 students enrolled in concept mapping program, upon the completion of the module, using concept mapping allow students to make new connections and expand their knowledge with clinical experiences [38]. Further, The results of [39] study showed that the degree of complexity of the concept maps increased overtime. Further, many studies showed that the large number of students does not hinder the effectiveness of concept mapping. Concept mapping was successfully applied in large classroom setting, and students were perceiving 
it positively [1] [40].

The next important finding from the current review was the improvement of cognitive abilities among nursing students. This finding was supported by the work of Vacek [41], which revealed that concept mapping is a significant predictor of students' abilities to understand psychoses as a complicated disorder. Also, a qualitative study of 12 semi-structured interviews found that concept mapping is a challenging learning approach and developing new cognitive skills [42]. These results were supported by many other studies in which critical thinking, deductive reasoning, and inductive reasoning were improved significantly with concept mapping [43] [44]. However, this finding was inconsistent with Samawi [23] study, which found that after applying the concept mapping, the post test scores of critical thinking did not differ significantly, also, nursing students who used concept mapping showed no increase in their critical thinking disposition post-test scores. Therefore, it is very important to implement concept maps gradually and it is suggested to integrate it early with traditional lectures [45].

The last finding in this review was related to students' abilities to more competent nurses in their clinical areas. Experimental studies showed that students were appreciated their abilities to integrate the learned knowledge in clinical settings, and they were creatively drawn concept maps for their patients including nursing care plan for each patient [2] [46]. Further, nursing students feeling satisfied and experiencing positive attitude toward clinical simulation and scenarios after utilizing concept maps in their clinical training [47] [48].

\section{Conclusions}

An interest in the potential value of concept mapping in nursing education has seen popularity over the last decade. Overall, the literature supports the need to include concept mapping as a teaching strategy in nursing curriculum. In this regard, we found in this review that the outcomes of utilizing concept mapping in nursing education are positive and interesting. We especially highlight the importance of the concept mapping in eliminating the passive role of students during the learning process. Actually, learning became more student centered rather than content centered. Also, we found that concept maps plying a vital role in constructing students' knowledge, according to that, the meaningful learning can be assured as students able to integrate already known knowledge with the new learned material.

Another finding in this review was related to the functionality of concept mapping in developing and improving students' cognitive ability, inductive reasoning, and critical thinking. Finally, from this review, many studies were emphasized the significance of concept mapping in nursing practice. It has been revealed that concept maps are support long-term learning, eases the transition from theory to real clinical practice, and reinforce students' self-confidences to work with patients. 
This review's results might suggest where nursing educators may begin to evaluate their teaching strategies. Also, since nursing students are see themselves as lifelong learners, this review might be helpful to shift nursing education from short-term to broader long-term goals and outcomes [49]. In addition, concept mapping could directly benefit student interactions with their learning environment, motivating teaching methods, and supporting the idea of meaningful learning [50].

However, as any other research work, several limitations to this review have been recognized. The sample size was small and heterogeneous, also, some selected articles were not experimental studies, using purposeful or convenient sampling methods, and depend only on one data collection strategy. All these factors might rise issues related to the statistical rigorous of their conclusions. However, findings often form a common thread, which will be a base for more future studies.

\section{References}

[1] Abel, W. and Freeze, M. (2006) Evaluation of Concept Mapping in an Associate Degree Nursing Program. Journal of Nursing Education, 45, 365-364.

[2] Aberdeen, S., Leggat, S. and Barraclough, S. (2010) Concept Mapping: A Process to Promote Staff Learning and Problem-Solving in Residential Dementia Care. Dementia, 9, 129-151. https://doi.org/10.1177/1471301209354022

[3] Atay, S. and Karabacak, Ü. (2012) Care Plans Using Concept Maps and Their Effects on the Critical Thinking Dispositions of Nursing Students. International Journal of Nursing Practice, 18, 233-239.

https://doi.org/10.1111/j.1440-172X.2012.02034.x

[4] Ausubel, D. (1963) The Psychology of Meaningful Verbal Learning. Grune \& Stratton, New York.

[5] Ausubel, D. (1968) Educational Psychology: A Cognitive View. Rinehart \& Winston, New York.

[6] Bixler, G., Brown, A., Way, D., Ledford, C. and Mahan, J. (2015) Collaborative Concept Mapping and Critical Thinking in Fourth-Year Medical Students. Clin. Pediatr., Philadelphia.

[7] Carr-Lopez, S., Galal, S., Deepti , V., Patel, R. and Gnesa, E. (2014) The Utility of Concept Maps to Facilitate Higher-Level Learning in a Large Classroom Setting. American Journal of Pharmaceutical Education, 78, 1-7.

https://doi.org/10.5688/ajpe789170

[8] Castellino, A. and Schuster, P. (2002) Evaluation of Outcomes in Nursing Students Using Clinical Concept Map Care Plans. Nurse Educator, 27, 149-150. https://doi.org/10.1097/00006223-200207000-00001

[9] Chabeli, M. (2010) Concept-Mapping as a Teaching Method to Facilitate Critical Thinking in Nursing Education: A Review of the Literature. Journal of Interdisciplinary Health Sciences, 15, 1-7. https://doi.org/10.4102/hsag.v15i1.432

[10] Chang, K., Sung, Y. and Chen, I. (2002) The Effect of Concept Mapping to Enhance Text Comprehension and Summarization. Journal of Experimental Education, 71, 5-23. https://doi.org/10.1080/00220970209602054

[11] Chen, L., Liang, T., Lee, M.-L. and Liao, I.-C. (2011) Effects of Concept Map 
Teaching on Students' Critical Thinking and Approach to Learning and Studying. Research Briefs, 50, 466-469.

[12] Chen, S., Liang, T., Lee, M. and Liao, I. (2011) The Effects of Concept Maps on Students' Critical Thinking and Approach to Learning and Studying. Journal of Nursing Education, 50, 466-469. https://doi.org/10.3928/01484834-20110415-06

[13] Conceicao, S. and Taylor, L. (2007) Using a Constructivist Approach with Online Concept Maps: Relationship between Theory and Nursing Education. Nursing Education Perspectives, 28, 368-375.

[14] Cook, L., Dover, C., Dickson, M. and Colton, D. (2012) From Care Plan to Concept map: A Paradigm Shift. Teaching and Learning in Nursing, 7, 88-92. https://doi.org/10.1016/j.teln.2011.11.005

[15] Dearmon, V., Lawson, R. and Hall, H. (2011) Concept Mapping a Baccalaureate Nursing Program: A Method for Success. Journal of Nursing Education, 50, 656-659. https://doi.org/10.3928/01484834-20110817-01

[16] Farrag, R. (2017) Concept Mapping Strategy: An Effective Tool for Improving Maternity Nursing Students' Achievement. Journal of Nursing Education and Practice, 7, 10-19.

[17] Forber, J., DiGiacomo, M., Carter, B., Davidson, P., Phillips, J. and Jackson, D. (2016) In Pursuit of an Optimal Model of Undergraduate Nurse Clinical Education: An Integrative Review. Nurse Education in Practice, 21, 83-92. https://doi.org/10.1016/j.nepr.2016.09.007

[18] Ghojazadeh, M., Aghaei, M., Naghavi-Behzad, M., Piri, R., Hazrati, H. and Azami-Aghdash, S. (2014) Using Concept Maps for Nursing Education in Iran: A Systematic Review. Research \& Development in Medical Education, 3, 67-72.

[19] Hagell, P., Edfors, E., Hedin, G., Westergren, A. and Hammarlund, C. (2016) Group Concept Mapping for Evaluation and Development in Nursing Education. Nurse Education in Practice, 20, 147-153. https://doi.org/10.1016/j.nepr.2016.08.006

[20] Harris, C. and Zha, S. (2014) Concept Mapping: A Critical Thinking Technique. Education, 134, 207-211.

[21] Harrison, S. and Gibbons, C. (2013) Nursing Student Perceptions of Concept Maps: From Theory to Practice. Nursing Education Perspectives, 34, 395-399. https://doi.org/10.5480/10-465

[22] Hill, C. (2006) Integrating Clinical Experiences into the Concept Mapping Process. Nurse Educator, 33, 36-39. https://doi.org/10.1097/00006223-200601000-00010

[23] Hsu, L.-L. (2004) Developing Concept Maps from Problem-Based Learning Scenario Discussions. Journal of Advanced Nursing, 48, 510-518. https://doi.org/10.1111/j.1365-2648.2004.03233.x

[24] Hsu, L.-L., Pan, H.-C. and Hsieh, S.-I. (2016) Randomized Comparison between Objective-Based Lectures and Outcome-Based Concept Mapping for Teaching Neurological Care to Nursing Students. Nurse Education Today, 37, 83-90. https://doi.org/10.1016/j.nedt.2015.11.032

[25] Huang, Y.-C., Chen, H.-H., Yeh, M.-L. and Chung, Y.-C. (2012) Case Studies Combined with or without Concept Maps Improve Critical Thinking in Hospital-Based Nurses: A Randomized-Controlled Trial. International Journal of Nursing Studies, 49, 747-754. https://doi.org/10.1016/j.ijnurstu.2012.01.008

[26] Jaafarpour, M., Aazami, S. and Mozafari, M. (2016) Does Concept Mapping Enhance Learning Outcome of Nursing Students? Nurse Education Today, 36, 129-132. https://doi.org/10.1016/j.nedt.2015.08.029 
[27] Kaddoura, M., Van-Dyke, O. and Yang, Q. (2016) Impact of a Concept Map Teaching Approach on Nursing Students' Critical Thinking Skills. Nursing and Health Sciences, 18, 350-354. https://doi.org/10.1111/nhs.12277

[28] Kaddoura, M., VanDyke, O., Cheng, B. and Shea-Foisy, K. (2016) Impact of Concept Mapping on the Development of Clinical Judgment Skills in Nursing Students. Teaching and Learning in Nursing, 11, 101-107. https://doi.org/10.1016/j.teln.2016.02.001

[29] Lee, W., Chiang, C.-H., Liao, I.-C., Lee, M.-L., Chen, S.-L. and Liang, T. (2013) The Longitudinal Effect of Concept Map Teaching on Critical Thinking of Nursing Students. Nurse Education Today, 33, 1219-1223. https://doi.org/10.1016/j.nedt.2012.06.010

[30] MacNeil, M. (2007) Concept Mapping as a Means of Course Evaluation. Journal of Nursing Education, 46, 232-234.

[31] Miller, L., Rosas, S. and Hall, K. (2011) Using Concept Mapping to Describe Sources of Information for Public Health and School Nursing Practice. Journal of Research in Nursing, 17, 466-481. https://doi.org/10.1177/1744987111403883

[32] Nirmala, T. and Shakuntala, B. (2011) Effect of Concept Mapping in Development of Critical Thinking Skills among Bachelor of Science Nursing Students. Journal of Health Sciences, 1, 20-25.

[33] Noonan, P. (2011) Using Concept Maps in Preioperative Education. AORN Journal, 94, 469-478. https://doi.org/10.1016/j.aorn.2011.02.013

[34] Novak (2010) Learning, Creating, and Using Knowledge: Concept Maps as Facilitative Tools in Schools and Corporations. Journal of E-Learning and Knowledge Society, 6, 21-30.

[35] Novak, J. and Gowin, B. (1984) Learning How to Learn. Port Chester, New York. https://doi.org/10.1017/CBO9781139173469

[36] Pilcher, J. (2011) Teaching and Learning with Concept Maps. National Network, 30, 336-339. https://doi.org/10.1891/0730-0832.30.5.336

[37] Revell, S. (2012) Concept Maps and Nursing Theory: A Pedagogical Approach. Nurse Educator, 37, 131-135. https://doi.org/10.1097/NNE.0b013e31825041ba

[38] Samawi, Z. (2006) The Effect of Concept Mapping on Critical Thinking Skills and Dispositions of Junior and Senior Baccalaureate Nursing Students. The 2nd International Conference on Concept Mapping, San José, Costa Rica: Concept Maps. Theory, Methodology, Technology.

[39] Samawi, Z., Miller, T. and Haras, M. (2014) Using High-Fidelity Simulation and Concept Mapping to Cultivate Self-Confidence in Nursing Students. Nursing Education Perspectives, 35, 408-409. https://doi.org/10.5480/12-1042.1

[40] Sarhangi, F., Masumi, M., Ebadi, A., Seyyed, M. and Rahmani, A. (2010) Comparing the Effect of Lecture- and Concept Mapping Based Learning on Cognitive Learning Levels. Iranian Journal of Critical Care Nursing, 3, 1-5.

[41] Schneider, T., Lyons, J. and Khazon, S. (2013) Emotional Intelligence and Resilience. Personality and Individual Differences, 55, 909-914. https://doi.org/10.1016/j.paid.2013.07.460

[42] Smith, L. (2016) Utilizing Concept Maps to Enhance Critical Thinking in First Semester Nursing Students. ProQuest, 1-47.

[43] Taie, E. (2014) Concept Mapping as an Innovative Teaching Strategy to Enhance Cognitive Learning in Nursing Administration Course. International Journal for Innovation Education and Research, 2, 11-25. 
[44] Trevisani, M., Cohrs, C.R., Soares, M., Duarte, J., Mancini, F., Pisa, I. and Domenico, E. (2016) Evaluation of Learning in Oncology of Undergraduate Nursing with the Use of Concept Mapping. Journal of Cancer Education, 31, 533-540. https://doi.org/10.1007/s13187-015-0869-1

[45] Tseng, H., Chou, F., Wang, H. and Ko, H. (2011) The Effectiveness of Problem-Based Learning and Concept Mapping among Taiwanese Registered Nursing Students. Nurse Education Today, 31, 41-46. https://doi.org/10.1016/j.nedt.2010.11.020

[46] Vacek, J. (2007) Using a Conceptual Approach with Concept Mapping to Promote Critical Thinking. Journal of Nursing Education, 48, 45-48. https://doi.org/10.3928/01484834-20090101-11

[47] Vacek, J. (2009) Using a Conceptual Approach with a Concept Map of Psychosis as an Exemplar to Promote Critical Thinking. Journal of Nursing Education, 48, 49-53. https://doi.org/10.3928/01484834-20090101-12

[48] Wahl, S. and Thompson, A. (2013) Concept Mapping in a Critical Care Orientation Program: A Pilot Study to Develop Critical Thinking and Decision Making Skills in Novice Nurses. The Journal of Continuing Education in Nursing, 44, 455-460. https://doi.org/10.3928/00220124-20130916-79

[49] Wheeler, L. and Collins, S. (2003) The Influence of Concept Mapping on Critical Thinking in Baccalaureate Nursing Students. Journal of Professional Nursing, 19, 339-346. https://doi.org/10.1016/S8755-7223(03)00134-0

[50] Wilgis, M. and McConnell, J. (2008) Concept Mapping: An Educational Strategy to Improve Graduate Nurses' Critical Thinking Skills during a Hospital Orientation Program. The Journal of Continuing Education in Nursing, 39, 119-126.

https://doi.org/10.3928/00220124-20080301-12 